Open Access

\title{
Profitability and constraints to urban exotic vegetable production systems in the Kumasi metropolis of Ghana: a recipe for job creation
}

\author{
Camillus Abawiera Wongnaa ${ }^{{ }^{*}} \mathbb{D}$, Margaret Atosina Akuriba², Amissah Ebenezer ${ }^{1}$, Karen Sakyibea Danquah ${ }^{1}$ and \\ Danso Anthony Ofosu' ${ }^{1}$
}

*Correspondence: wongnaaa@
yahoo.com
${ }^{1}$ Department of Agricultural
Economics, Agribusiness and
Extension, Kwame Nkrumah
University of Science and
Technology, Kumasi, Ghana
Full list of author information is
available at the end of the article

* Correspondence: wongnaaa@ Economics, Agribusiness and Extension, Kwame Nkrumah available at the end of the article

\begin{abstract}
Some vegetable producers perceive their venture to be unprofitable owing to cheating at the farm gate. This study sought to determine profitability of production of exotic vegetables which are not native of Ghana. The study used data collected from 80 urban exotic vegetable farmers. Descriptive statistics, gross margin analysis, multiple linear regression, and the Garrett ranking scale were the methods of analysis. The most profitable system from the results of the net margin ratio was the production of lettuce as a sole crop with net margin ratio of $71 \%$ which explains the popularity of lettuce among exotic vegetable producers in the metropolis. Household size, experience, and access to credit positively affected profitability while farm size as well as costs of labor and fertilizer had negative effects. Farmers ranked high input cost, land tenure insecurity, and high cost of irrigation as challenges to urban exotic vegetable production. We recommend that urban exotic vegetable production should be considered as a source of employment. Government and financial institutions should improve farmer access to credit to enable them to hire adequate labor and acquire technologies and production inputs.
\end{abstract}

Keywords: Cabbage, Cost, Ghana, Lettuce, Production systems, Revenue, Spring onion

\section{Introduction}

In urban Ghana, food prices and household income are important economic parameters in accessing vegetables. Access to healthy vegetables is constrained by long distances and high cost of transportation from production sources (Badmus \& Yekinni, 2011). To mitigate this will mean the promotion of urban agriculture to make food and income available at the household level (Hoornweg \& Munro-Faure, 2008).

Urban vegetable production ensures food security, nutrition, and improved livelihoods through the provision of healthy diet and source of income for households (Hoornweg \& Munro-Faure, 2008). Commonly grown urban vegetables not native to Ghana include cabbage (Brassica oleracea var. capitata L.), lettuce (Lactuca sativa L.), spring onion (Allium fistulosum L.), bell pepper (Capsicum annuum L.), and cucumber (Cucumis sativus L.) (Cofie, Dreschel, Obuobie, Danso, \& Keraita, 2003a). These are 
normally sold at high prices across shops and sales point in the cities. Income generated from irrigated urban vegetable production is two to three times that of revenue accrued under traditional rainfed vegetable production (Danso, Drechsel, Wiafe-Antwi, \& Gyiele, 2002).

Despite benefits of urban vegetable production, it is not uncommon to hear claims of vegetable farmers feeling cheated at the farm gate creating the perception that vegetable production is unprofitable (Abdulai, Nimoh, Darko-Koomson, \& Kassoh, 2017). This perception exists because farmers mostly sell their vegetables at the farm gate at prices determined by traders (Drechsel \& Keraita, 2014). Farmers are thus unable to recover production cost which includes costs of irrigation, land, and soil fertility management (Danso et al., 2002; Obuobie et al., 2006).

A number of vegetable production systems (mono-cropping and mix-cropping) are practiced in urban centers. Literature on the most profitable system is however limited. This knowledge gap has the potential to affect investment decisions of prospective vegetable farmers and the entire industry. Therefore, this study was intended to fill the knowledge gap on the most profitable production system and also highlight constraints to production for effective policy formulation.

To overcome the uncertainties surrounding profitability of vegetable production in order to make the sector an avenue for job creation, knowledge of performance and constraints to existing vegetable production business is necessary. The overarching questions are the following: Do farmers still make profit by selling their vegetable produce at the farm gate? What is the most profitable vegetable production system? What factors influence the profitability of urban exotic vegetable production? What constraints militate against the profitability of vegetable production? To answer these critical questions, this study was undertaken to determine the profitability, its determinants, and constraints to urban exotic vegetable production. Findings from this study provide information on the profitability of urban exotic vegetable production for job creation.

\section{Literature review}

Several previous studies have reported on the costs, revenues, and profitability of urban vegetable production. The greatest factor influencing farmers' profits is not so much the yield obtained but producing at the right time what is in short demand and the ability to sell consistently at above average prices (Cornish \& Lawrence, 2001). According to Drechsel and Keraita (2014), leafy salad greens achieve the best revenues. Comparing profit as a percentage of production costs, the traditional mixed cultivation with oil palms ranked highest but would require much longer investment periods (Gyiele, 2002). Abban (2003) compared vegetable production in the urban production and commercial irrigation sectors of Ghana's Greater Accra Region with most of the farmers in each category practicing mix cropping. The findings were that the gross revenues were four times higher in formal irrigation schemes but also eight times the production costs. The resulting net returns still favored formal irrigation with an income twice as high as in informal urban irrigation. The benefit-cost ratio in the production period, however, was two times higher in urban agriculture, making it an interesting venture for migrants trying to establish a livelihood with little start-up capital and in need of 
quick returns. Comparing alternative farming systems, urban wastewater vegetable production in Ghana generates the highest net revenues per hectare based on a combination of lettuce, cabbage, and spring onion (Drechsel \& Keraita, 2014). Also, according to Badmus and Yekinni (2011), exotic vegetable farming is a profitable venture that requires little capital and has become a source of livelihood to the farmers in the business. The study added that profit can be maximized with improvements in access to extension services, use of insecticides, availability of exotic vegetable seeds, and provision of incentives to the exotic vegetable growers.

Urban vegetable farmers also face a number of constraints (Kouvonou, Honfoga, \& Debrah, 1999; Armar-Klemesu \& Maxwell (2000); Cofie, Van Veenhuizen, \& Drechsel, 2003b; Diao, 2004). The Medium Term Agriculture Sector Investment Plan (METASIP) mentions that urban farmers face constraints of access to land and quality water for irrigation (Drechsel \& Keraita, 2014). Crop production on urban open spaces appears to be a market-driven, highly productive, and profitable phenomenon (Drechsel, Graefe, Sonou, \& Cofie, 2006). However, it is often constrained by tenure insecurity and non-agricultural land demands. While market proximity supports urban farming, urban expansion constrains it. Also, the common use of polluted water limits the official support of irrigated urban farming. However, despite these constraints, the phenomenon of urban farming appears to be persistent and resilient to its changing environment, although individual farmers might have to shift to other sites when their plots are taken for construction (Drechsel \& Dongus, 2010). Generally, according to Drechsel and Keraita (2014), major constraints to urban vegetable production in Ghana include market women/buyers dictating produce prices at harvest; high cost of inputs; pest and disease threats to crops; inadequate amounts of cheap soil inputs (compost, poultry manure, etc.); lack of available land and tenure insecurity due to urban development; high labor input for watering of vegetables; lack of access to irrigation facilities; poor seed quality; inadequate source of funding; and limited support from extension services.

For the northerners who migrate to the southern cities of Ghana in search of jobs opportunities, urban vegetable production might be their first choice but could also be the second if they do not succeed otherwise because of low levels of education (Obuobie et al., 2006; Drechsel \& Keraita, 2014). In fact, the typical Ghanaian urban vegetable farmer is a male and within the 31-40-year age group who cultivates exotic vegetables like cabbage, cucumber, lettuce, onion, cauliflower, and green pepper on a land area of between 0.01 and 0.12 ha (Zallé, 1999; Judicom, 2004; Kessler, Streiffeler, \& Obuobie, 2004). Once he is established in producing vegetables, it becomes a serious business and he does not want to quit even when he finds better-salaried employment (Drechsel \& Keraita, 2014). A study conducted by Obosu-Mensah (1999) in Accra revealed that out of 200 urban farmers interviewed, 66\% had no intention of stopping farming even if they were offered regular-salaried employment. This was because open-space urban agriculture could bring in very good earnings in spite of the risks of crop loss and other issues. Those who indicated that they would stop one day mentioned general sickness or loss of land as major factors that could compel them to do this. In contrast to vegetable farming, women dominate the vegetable marketing sector, in particular retail, as also observed in neighboring countries (Armar-Klemesu \& Maxwell, 2000; Mbaye \& Moustier, 2000; Gerstl, 2001; Obuobie et al., 2006). Women's general dominance in retail is partly attributed to the Ghanaian tradition that retail in general is a woman's job, 
though with many exceptions (Drechsel \& Keraita, 2014). Some women traders can provide credit to producers with interest rates as high as 25\% (Kouvonou et al., 1999; Armar-Klemesu \& Maxwell, 2000; Kessler et al., 2004) and may have a higher income than their husbands who generally produce the vegetables (Kessler et al., 2004).

As one of the Resource Centres on Urban Agriculture and Food Security (RUAF), for many years, International Water Management Institute (IWMI) has facilitated a policy dialog on urban agriculture in Accra (Amerasinghe, Cofie, Labri, \& Drechsel, 2013). The work showed that officials interviewed in all major cities in Ghana usually acknowledge the importance of urban agriculture in providing food and jobs for unemployed urban dwellers or its contribution to preventing encroachment on both government and private lands. Authorities also believe that vegetable production in and around Ghanaian cities contributes to the supply of vegetables, which improves the nutritional level of urban diets (Gockowski, Mbazo'o, Mbah, \&Moulende, 2003; Kessler et al., 2004; Moustier, Moumbele, \& Huat, 2004; Temple, Minkoua, Nkendah, \& Marquis, 2005 Lee-Smith \& Prain, 2006; Drechsel \& Keraita, 2014). In Lomé and Accra, over $90 \%$ of the lettuce consumed in those cities are known to be produced through urban vegetable producers (Kouvonou et al., 1999; Cofie et al., 2003b). Also, more than 800,000 urban dwellers eat exotic vegetables daily on Ghana's streets, canteens, and restaurants. Most of the perishable vegetables are produced on open spaces in the cities or its fringes due to insufficient cold transport and storage, and according to Obuobie et al. (2006) and Drechsel and Keraita (2014), this activity is highly profitable and can lift vulnerable groups out of poverty. In fact, urban vegetable production is an important income generating activity and many urban dwellers rely on it as their main source of income, and in many cases, this income is equivalent to or higher than the salary of a senior civil servant and it is usually twice the income they would have earned in rural areas (Kouvonou et al., 1999; Zallé, 1999; Obuobie et al., 2006).

\section{Materials and methods}

\section{Study area}

This study was conducted in the Kumasi metropolis in the Ashanti region of Ghana. The metropolis is the capital of the Ashanti region and the most populous metropolis in the Ashanti region. The metropolis is located centrally in the Ashanti region, forming an important transport and commercial hub for both domestic and international traffic. It is located between latitude $6.35^{\circ} \mathrm{N}$ and $6.4^{\circ} \mathrm{S}$ and longitude $1.3^{\circ} \mathrm{N}$ and $1.35^{\circ} \mathrm{S}$ and elevated 250 to $300 \mathrm{~m}$ above sea level (GSS, 2014). The metropolis shares boundaries with Kwabre East and Afigya Kwabre Districts to the north, Atwima Kwanwoma and Atwima Nwabiagya Districts to the west, Asokore Mampong and Ejisu-Juaben Municipality to the east, and Bosomtwe District to the south. It is approximately $270 \mathrm{~km}$ north of the national capital (Accra) and located in the forest zone. It has a total land area of $254 \mathrm{~km}^{2}$. Vegetation in the metropolis is dense with a bimodal rainfall pattern with a short dry period (Abdulai, 2006).

The metropolis has a population of $1,730,249$ which represents $36.2 \%$ of the total population of the Ashanti region (Population Census, 2010). About 38.9\% of the working population is engaged as service and sales workers, followed by craft and related trade workers (22.8\%). About $49.2 \%$ of the workforce in the metropolis are 
self-employed (GSS, 2014). The informal sector is the largest employer in the metropolis, employing over $79 \%$ of the employed population (KMA, 2016). About $8.5 \%$ of households in the metropolis are engaged in agricultural activities of which $91.6 \%$ of the population engage in the production of crops.

Agriculture in Kumasi consists of crop production, aquaculture, horticulture, and some animal rearing. Crop production is limited to small scale production of staple crops such as; maize (Zea mays L.), plantain (Musa paradisiaca L.), cocoyam (Xanthosoma sagittifolium L.Schott), cassava (Manihot esculenta Crantz), tomatoes (Lycopersicon esculentum Mill.), and pepper (Capsicum spp. L). Exotic vegetables such as carrots (Daucus carota L.) and cabbage are produced in the peri-urban areas of the metropolis. Important streams and rivers in the metropolis include Owabi, Subin, and Wiwiso. The metropolis also has a number of inland valleys suitable for vegetable production (Drechsel et al., 2006).

\section{Sampling procedure}

The population for this study was members of the vegetable growers' association in the Kumasi metropolis of Ghana. Using Yamane's (1967) sample size determination formula, the minimum sample size for the study was calculated such that

$$
n=\frac{N}{1+N(e)^{2}}
$$

where $n$ is the sample size, $N$ is the population size, and $e$ is the level of precision.

At the time of data collection, the association had a total membership of 323. Adopting a $95 \%$ confidence level, a degree of variability $(p=0.5)$ and a level of precision or sampling error $(e=10 \%)$, the minimum required sample size was

$$
n=\frac{323}{1+323(0.1)^{2}}=\frac{323}{1+323(0.01)}=\frac{323}{1+3.23}=\frac{323}{4.23}=76.35
$$

Using a two-stage sampling approach, 80 exotic vegetable producers were sampling taking into account the probability of no responses. The first stage of the sampling procedure was the random sampling of five major production sites from a list of 10 provided by the association. The sampled sites were Anloga, Kaasi, Ahensan, Atonsu, and Kwame Nkrumah University of Science and Technology (KNUST) campus. The second stage was the simple random sampling of 16 exotic vegetable producers from a list of vegetable producers in each sampled site.

\section{Data collection}

The source of data for this study was the primary data from farmers who are involved in urban exotic vegetable production in the Kumasi metropolis. Vegetables considered in this study included exotic leafy vegetables which are produced all year round and consumed primarily as salad. Data collection was through the use of a structured questionnaire administered through face-to-face interviews. Data collected included socioeconomic characteristics, land tenure, labor, access to credit, uses of farm inputs, agricultural extension service, agricultural equipment, output, and marketing as well as constraints to vegetable production. 


\section{Methods of data analysis}

This study employed descriptive statistics in describing the socioeconomic characteristics of respondents. Production cost was estimated based on average production cost per acre. Revenue was estimated as a product of output prices and quantity per acre. Gross margin and net returns analysis were used as a measure of profitability. This was in line with Adegey and Dittoh (1982) who stated that gross margin was a good measure of profitability. Algebraically, profitability was estimated as:

$$
\begin{aligned}
& \mathrm{GM}=\mathrm{TR}-\mathrm{TVC} \\
& \mathrm{NT}=\mathrm{TR}-\mathrm{TC}
\end{aligned}
$$

where GM was gross margin, TR as total revenue, TVC as total variable, NT as net margin, and TC as the total cost of production. The gross margin was expressed against the total revenue as a percentage to determine the productivity of a Ghana Cedi (Ght) of revenue generated. The net margin is expressed against total revenue as a percentage to determine the productivity of a cedi of net returns. Analysis of variance (ANOVA) was used to investigate whether there were differences in costs and revenues between the production systems (Okurut \& Botlhole, 2009).

Evaluation of the determinants of the profitability of vegetable farmers was conducted using a multiple linear regression model analysis. Gross margin per acre was the dependent variable. This was regressed against a number of independent variables such that

$$
\begin{aligned}
& y=f\left(x_{1}, x_{2}, \ldots \ldots \ldots x_{k}\right)+u \\
& y=x_{1} \beta+x_{2} \beta+\ldots \ldots .+x_{k} \beta+u
\end{aligned}
$$

where

$y=$ Dependent or explained variable,

$x_{1}, x_{2}, \ldots x_{k}=$ Independent or explanatory variables,

$\beta=$ Parameters of the explanatory variables,

$u=$ Error term or random disturbance.

The parameters were estimated using ordinary least squares (OLS) procedure. The hypothesis

$$
\begin{aligned}
& H_{0}: \beta_{i}=0 \\
& H_{A}: \beta_{i} \neq 0
\end{aligned}
$$

was tested using the Student $t$ statistic as specified in Eqs. (6) and (7)

$$
t_{\beta_{i}}=\frac{\beta_{i}}{\operatorname{SE}\left(\beta_{i}\right)}
$$

where $t=t$ ratio for the estimator $\beta_{i}$ and $\operatorname{SE}\left(\beta_{i}\right)=$ standard error of the parameter $\beta_{i}$.

$$
F=\frac{R^{2} /(k-1)}{\left(1-R^{2}\right) /(n-k)}
$$

wheren $=$ number of observations,

$k=$ number of explanatory variables including the constant,

$R^{2}=$ coefficient of determination . 
The multiple linear regression model was employed because it allows quantification of the effect of key determinants of profitability obtained from urban exotic vegetable production. The empirical model was specified as in Eq. (8):

$$
\begin{aligned}
y= & \beta_{0}+\beta_{1} X_{1}+\beta_{2} X_{2}+\beta_{3} X_{3}+\beta_{4} X_{4}+\beta_{5} X_{5}+\beta_{6} X_{6}+\beta_{7} X_{7}+\beta_{8} X_{8}+\beta_{9} X_{9} \\
& +\beta_{10} X_{10}+\beta_{11} X_{11}+\beta_{12} X_{12}+\varepsilon_{i}
\end{aligned}
$$

where $y$ is the profitability of vegetable production, measured by gross margins per acre; $X_{i}$ are explanatory variables, with their descriptions, measurements, and expected signs presented in Table $1 ; \beta_{i}$ are estimated coefficients of the explanatory variables; and $\varepsilon_{i}$ is the error term.

Finally, Garrett's ranking method was used to assess the relative significance of problems associated with urban exotic vegetable production (Garett \& Woodworth, 1969). Respondents were asked to rank production problems in relation to exotic vegetable cultivation in urban areas. The percent position of each rank obtained was converted into scores. For each factor, scores of individual respondents were added together and divided by the total number of respondents for whom scores were obtained, and based on mean scores, ranks were assigned. The individual's ranks were converted into percentage positions for each of the assigned rank by using the formula:

$$
\frac{100\left(R_{i j}-0.5\right)}{N_{j}}
$$

where $R_{i j}$ is the rank position and $N_{j}$ is the number of constraints.

The Garrett scale value for ranks $1,2,3,4$, and 5 is $79,66,57,50$, and 43 , respect-

\begin{tabular}{|c|c|c|c|}
\hline Variables & Measurement of variables & Category & $\begin{array}{l}\text { Expected } \\
\text { sign }\end{array}$ \\
\hline Age of farmer $\left(X_{1}\right)$ & Number of years & Continuous & - \\
\hline Educational level $\left(X_{2}\right)$ & Years of schooling & Continuous & + \\
\hline $\begin{array}{l}\text { Household size of the } \\
\text { farmer }\left(X_{3}\right)\end{array}$ & Number of family members & Continuous & + \\
\hline Experience $\left(X_{4}\right)$ & Number of years in farming & Continuous & + \\
\hline Cost of labor $\left(X_{5}\right)$ & Ghana Cedi (Ghל̧) & Continuous & - \\
\hline Access to credit $\left(X_{6}\right)$ & 1 if access, 0 otherwise & Dummy & + \\
\hline Price of manure $\left(X_{7}\right)$ & Ghana Cedi (Ghלे) & Continuous & - \\
\hline Price of pesticide $\left(X_{8}\right)$ & Ghana Cedi (Ghלे) & Continuous & - \\
\hline Price of fungicide $\left(X_{9}\right)$ & Ghana Cedi (Ghל̧) & Continuous & - \\
\hline Price of output $\left(X_{10}\right)$ & Ghana Cedi (Ghל̧) & Continuous & + \\
\hline Farm size $\left(X_{11}\right)$ & Acres & Continuous & + \\
\hline Farm tools $\left(X_{12}\right)$ & $\begin{array}{l}\text { Depreciation using the straight line method }= \\
\frac{\text { cost of the asset-salvage value }}{\text { useful life of the asset }}\end{array}$ & Continuous & - \\
\hline
\end{tabular}
ively. Also, the respective Garrett percentages are 7, 21, 36, 50, and 64 .

Table 1 Description of the independent variables used in the profitability model 


\section{Results and discussion}

\section{Socio-demographic characteristics of the respondents}

Exotic vegetable production in the Kumasi metropolis was male-dominated such that 96.3\% of respondents were males with $3.8 \%$ being females (Table 2). This result is in

Table 2 Socio-demographic characteristics of the respondents

\begin{tabular}{|c|c|c|}
\hline Variables & Frequency & Percentage \\
\hline \multicolumn{3}{|l|}{ Sex } \\
\hline Male & 77 & 96.3 \\
\hline Female & 3 & 3.7 \\
\hline Total & 80 & 100 \\
\hline \multicolumn{3}{|l|}{ Age range } \\
\hline $18-45$ & 62 & 77.5 \\
\hline $46-60$ & 18 & 22.5 \\
\hline Total & 80 & 100 \\
\hline \multicolumn{3}{|l|}{ Marital status } \\
\hline Married & 63 & 79 \\
\hline Single & 14 & 17 \\
\hline Divorced & 3 & 4 \\
\hline Total & 80 & 100 \\
\hline \multicolumn{3}{|l|}{ Educational level } \\
\hline No formal education & 16 & 20 \\
\hline Primary school & 11 & 14 \\
\hline Middle/JSS/JHS & 31 & 39 \\
\hline SSS/SHS & 18 & 22 \\
\hline Training college/Tertiary & 4 & 5 \\
\hline Total & 80 & 100 \\
\hline \multicolumn{3}{|l|}{ Occupation of respondents } \\
\hline Public service and vegetable farming & 7 & 9 \\
\hline Trading/commerce and vegetable farming & 14 & 17 \\
\hline Artisan and vegetable farming & 13 & 16 \\
\hline Vegetable farming only & 46 & 58 \\
\hline Total & 80 & 100 \\
\hline \multicolumn{3}{|l|}{ Production system } \\
\hline Lettuce only & 19 & 24 \\
\hline Spring onions & 2 & 2 \\
\hline Lettuce and spring onion & 30 & 37 \\
\hline Lettuce, cabbage, and spring onions & 18 & 23 \\
\hline Cabbage and lettuce & 11 & 14 \\
\hline Total & 80 & 100 \\
\hline \multicolumn{3}{|l|}{ Sales outlet } \\
\hline Institutions & 1 & 1 \\
\hline Market women & 69 & 86 \\
\hline Market women and individuals & 10 & 13 \\
\hline Total & 80 & 100 \\
\hline
\end{tabular}

Source: Field Survey, 2017 
line with previous studies (Obuobie et al., 2006; Kouamé, Temple, Levasseur, \& Pasquini, 2006; Van Veenhuizen \& Danso, 2007; Drechsel \& Keraita, 2014; Abdulai et al., 2017). Farmers were relatively young with an average age of 37 years which depicts a promising future for urban exotic vegetable production. This age distribution corroborates results of Obuobie et al. (2006), Drechsel \& Keraita (2014), and Abdulai et al. (2017). The educational distribution of respondents shows that at least $75 \%$ of urban exotic vegetable producers had formal education (Table 2). This is consistent with the findings of Abdulai et al. (2017) even though it disagrees with those of Drechsel \& Keraita (2014) that many urban open-space farmers do not have access to formal education. Most respondents (58\%) were into vegetable production as a major occupation and a main source of income. This corroborates similar results reported by Drechsel \& Keraita (2014). About $42 \%$ of the respondents were engaged in other income economic activities such as public service, trading, and artisanal works. The most common vegetable system practiced in the study area was the cultivation of spring onion and lettuce $(37 \%)$ on the same piece of land at the same time (Table 2). This was followed by cultivation of only lettuce (24\%); simultaneous cultivation of cabbage, lettuce, and spring onion (23\%); cultivation of lettuce and cabbage; and finally cultivation of only spring onion $(2 \%)$. This result agrees with Drechsel \& Keraita (2014) that urban vegetable producers do not normally go into sole cultivation of any vegetable at any point in time but cultivate a combination of two or more.

Farmers in the study area sold their products through three main sales outlets namely through market women, individual consumers, and institutions (Table 2). Results show that the most preferred sales outlet was through market women (86\%). This is in line with the findings of Drechsel \& Keraita (2014) who stated that the largest clients of exotic vegetable marketing chain are the fast food sellers, buying 60\% of vegetables in Accra and 83\% in Kumasi.

Average household size was five persons per household (Table 3) which served as a source of family labor to complement hired labor. This compares well with similar results reported by Obuobie et al. (2006), Drechsel \& Keraita (2014), and Abdulai et al. (2017). Farmers on the average had 9 years of experience in urban exotic vegetable production (Table 3) which is in line with Obuobie et al. (2006) and Drechsel \& Keraita (2014). Finally, the average farm holding of the urban vegetable farmer was 1.7 ac (Table 3). This was due to the constraint associated with accessing land at urban centers (Drechsel \& Keraita, 2014).

Table 3 Descriptive statistics of farmers' characteristics

\begin{tabular}{llll}
\hline Variables & Minimum & Maximum & Average \\
\hline Household size & 1 & 15 & 4.7 \\
Age of farmers (years) & 20 & 60 & 36.7 \\
Education (years of schooling) & 0 & 16 & 8.4 \\
Farming experience (years) & 1 & 25 & 8.7 \\
Farm size (acres) & 0.25 & 5 & 1.7 \\
\hline
\end{tabular}

Source: Field Survey, 2017 


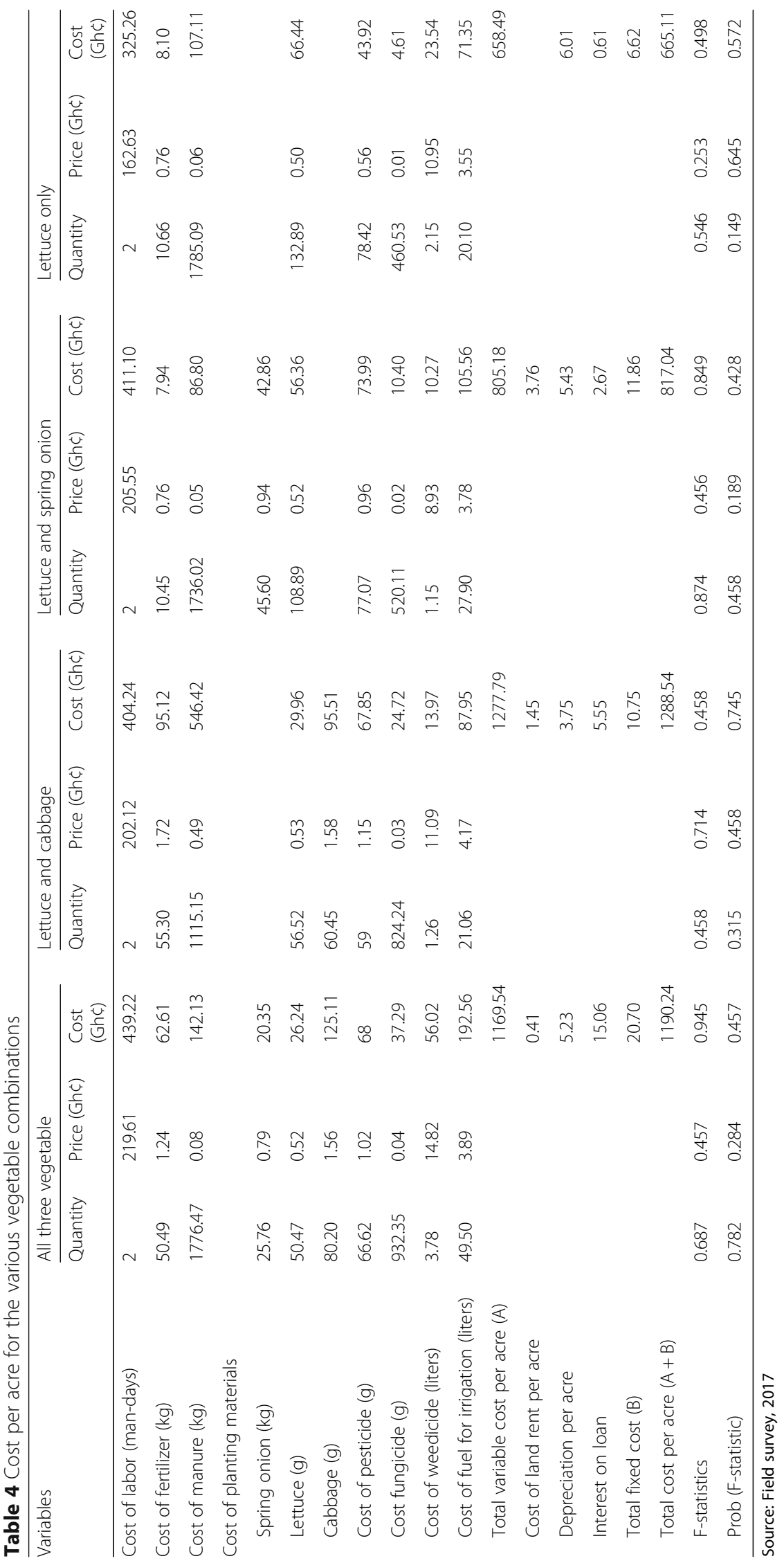


Costs and revenues per acre for the various vegetable production systems

Table 4 presents the cost structure of engaging in different vegetable production systems. On the average, the total variable cost was Gh\$1 $169.54^{1}$ per acre for farmers cultivating all the three exotic vegetables (lettuce, cabbage, and spring onions). Farmers who cultivated lettuce and cabbage together incurred a cost of Gh\$1277.79 per acre as total variable cost. Lettuce and spring onion production system led to a total variable cost of Ghథ805.18 per acre. Total variable cost for sole lettuce was Ghథ658.49 per acre (Table 4).

Total fixed cost incurred by farmers were Ghథ20.70, Ghథ10.75, Gh\$11.86, and Ghథ 6.62 per acre for three exotic vegetable crops, lettuce and cabbage, lettuce and spring onion, and sole lettuce, respectively. Therefore, the total production cost for three exotic vegetable crops, lettuce and cabbage, lettuce and spring onion, and sole lettuce production were Gh\$1190.24, Ghథ1288.54, Ghథ817.0, and Ghథ655.11 per acre, respectively (Table 4). This result compares well with Abdulai et al. (2017) findings on spring onions production in the Kumasi metropolis of Ghana.

Table 5 presents the revenues generated per acre of the various vegetable production systems. The results revealed that the revenue generated for cultivating all three exotic vegetables was Gh\$2907.9 per acre. For lettuce and cabbage combination, the total revenue was Gh\$3756.17 per acre, whereas the total revenue stood at Ghథ1898.17 for lettuce and spring onion combination. Finally, for farmers who cultivated lettuce as a sole vegetable crop, their total revenue was estimated to be Gh\$2292.8. The revenues generated in this study for the various vegetable production systems are consistent with revenues reported by Van Veenhuizen and Danso (2007) as well as Abdulai et al. (2017) for urban vegetable production in similar previous studies.

\section{Profitability of alternative vegetable production systems}

From Table 6, farmers who produced all the three vegetables had a gross margin of Gh \$1738.54 per acre which represented $59.78 \%$ of their total revenue. Farmers who were into lettuce and cabbage production had a gross margin of Gh $\$ 2478.38$ per acre representing $65.98 \%$ of the revenue. Those who were into lettuce and spring onion production had a gross margin of Gh\$1092.99 per acre representing $57.58 \%$ of revenue. Finally, the farmers who were into only lettuce cultivation had a gross margin of Ghc 1634.31 per acre representing $71.3 \%$ of the total revenue.

The net margin for the farmers who produced all the three vegetables was Ghe 1717.66 per acre representing $59.06 \%$ of total revenue. The farmers who were into lettuce and cabbage production had Gh\$2467.63 per acre as their net margin representing $65.69 \%$ of the revenue. Those who were into lettuce and spring onion production had a net margin of Gh\$1081.18 per acre representing 56.96\% of the gross revenue with farmers who cultivated only lettuce with a net margin of Gh\$1627.69 per acre representing $71 \%$ of the total revenue.

Based on gross margins and net returns from this study, it is clear that urban exotic vegetable production, irrespective of production system, is profitable. The most profitable system from the results of the net margin ratio however was the production of lettuce as a sole crop with a net margin ratio of $71 \%$ which explains the popularity of lettuce among exotic vegetable producers in the metropolis. This profitability results are in line with similar 


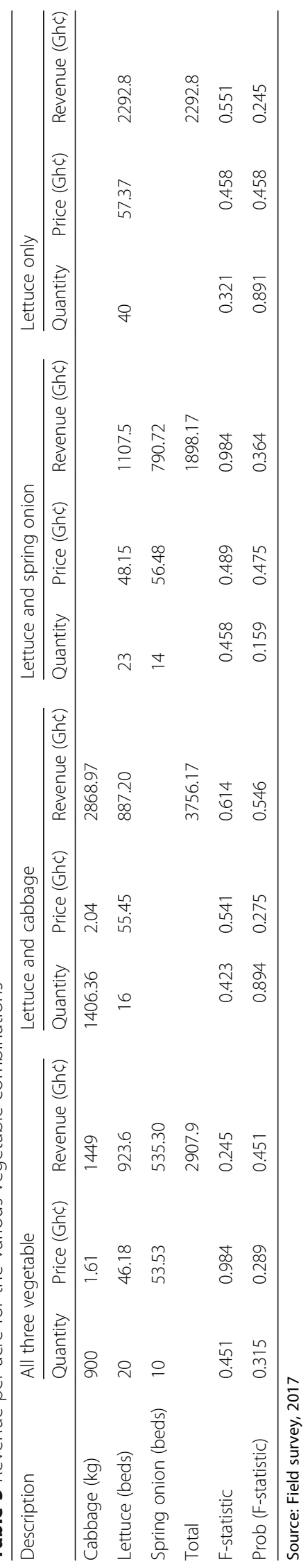


Table 6 Gross margin and net margin per acre

\begin{tabular}{lllll}
\hline Cost/revenue & All three vegetable & Lettuce and cabbage & Lettuce and spring & Lettuce only \\
\hline Revenue per acre (Ghל̧) & 2907.9 & 3756.17 & 1898.17 & 2292.8 \\
Total variable cost (Ghc) & 1169.54 & 1277.79 & 805.18 & 658.49 \\
Gross margin (Ghç) & 1738.54 & 2478.38 & 1092.99 & 1634.31 \\
Gross margin ratio (\%) & $59.78 \%$ & $65.98 \%$ & $57.58 \%$ & $71.3 \%$ \\
Fixed cost (Ghç) & 20.70 & 10.75 & 11.8 & 6.62 \\
Total cost (Ghç) & 1190.24 & 1288.54 & 817.04 & 665.11 \\
Net margin (Ghc) & 1717.66 & 2467.63 & 1081.18 & 1627.69 \\
Net margin ratio (\%) & $59.06 \%$ & $65.69 \%$ & $56.96 \%$ & $71 \%$ \\
F-statistic & 0.894 & 0.547 & 0.614 & 0.578 \\
Prob (F-statistic) & 0.589 & 0.459 & 0.127 & 0.987 \\
\hline
\end{tabular}

Source: Field survey, 2017

previous performance studies (Kassali, 2011; Ndungu, Macharia, \& Kahuthia-Gathu, 2012; Angula, Thomas, \& Ijambo, 2014; Kuwornu et al., 2018; Mariyono, 2018).

\section{Factors influencing profitability of alternative vegetable production systems}

The coefficient of determinations $\left(R^{2} \mathrm{~s}\right)$ of the regression models were high indicating the robustness of the models. That is, a greater proportion of the variations in the profitability of each production system can be explained by changes in the explanatory variables.

The coefficient of age was negative and statistically significant at the $10 \%$ level for lettuce and spring onions production. This implies that an increase in the age of the vegetable farmer by 1 year will decrease his/her profit by Gh\$41.9. This negative relationship could be due to the labor-intensive nature of vegetable production. Therefore, as the farmer gets older, he/she becomes weaker and unable to provide the needed labor for production. This finding is consistent with the findings of Masuku and Xaba (2013) even though it disagrees with that of Ndungu et al. (2012).

The educational level of farmers had a positive relationship with profitability for each of the production systems and was statistically significant (Table 7) which was consistent with Angula et al. (2014). This positive relationship meant an additional year in school led to an increase in profitability by Gh\$25.51 per acre for production of all three vegetables, Gh\$48.61 for cultivating lettuce and cabbage, Gh\$54.78 for cultivating lettuce and spring onion, and Gh\$47.74 for cultivating only lettuce.

Household size was significant and positively related to profitability. An increase in household size by one extra member did increase profitability by Gh\$42.06, Gh\$58.81, and Gh\$86.46 for the pooled sample, producers of all three vegetables, and sole lettuce producers, respectively (Table 7 ). This positive relationship existed as households provided family labor to complement hired labor. Masuku and Xaba's (2013) report of a positive relationship between family size and profitability of vegetable production in Swaziland is in line with this finding.

Farmer experience in vegetable production was positive and statistically significant for the pooled sample; production of all three vegetables, lettuce, and cabbage; and lettuce and spring onion. This finding is similar to those of previous studies such as 


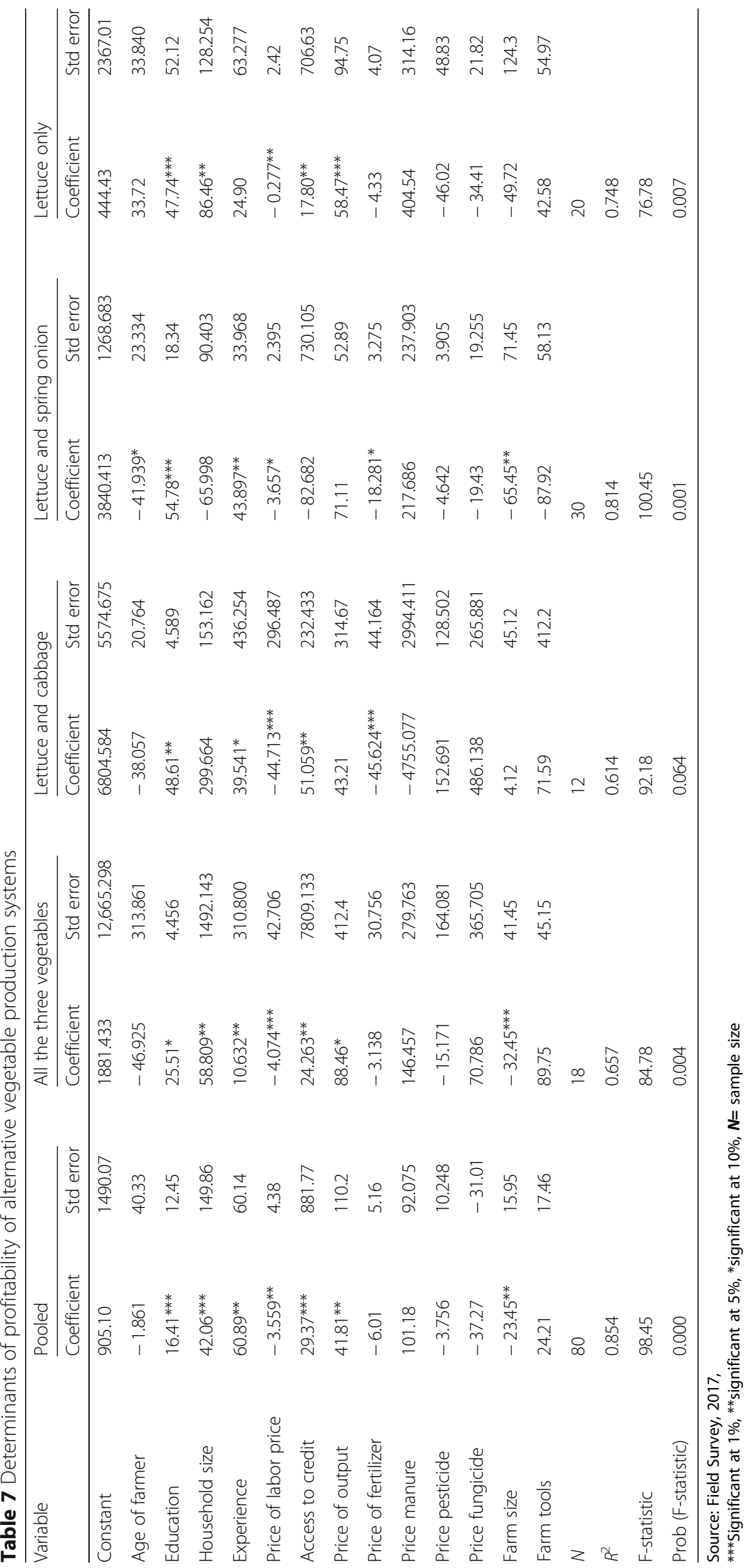


Demiryurek \& Ceyhan (2008), Oxouzi \& Papanagiotou (2010), and Ndungu et al. (2012). The positive relationship led to Gh\$10.63, Gh\$39.54, and Gh $\$ 43.90$ increase in profitability for producers of all three vegetables, lettuce, and cabbage as well as lettuce and spring onion, respectively (Table 7) with a year increase in farmer experience. This was due to the fact that experienced farmers over the years have had the opportunity of incorporating into their production system improved production technologies for enhanced productivity which is a prerequisite for profitability.

Access to credit was positively related to profitability for farmers involved in production of all three vegetables, lettuce, and cabbage, as well as sole lettuce production. This was due to the ability of credit to create the opportunity for input acquisition and other services. From Table 7, an increase in credit by one Ghana Cedi led to an increase in profitability of farmers producing all three vegetables by Gh\$24.26, lettuce and cabbage by Gh\$51.06, and sole lettuce production by Ghథ 17.80. Masuku and Xaba's (2013) findings of a positive effect of credit on the productivity of vegetables align with this finding.

Price of output was positively related to the profitability of having all vegetables on the farm as well as having only lettuce on the farm and was statistically significant at $10 \%$ and $1 \%$, respectively. This meant an increase in output price by one Ghana Cedi led to an increase in profit by Gh\$88.46 and Gh\$58.47 for producing all three vegetables and sole lettuce, respectively (Table 7).

Cost of labor was statistically significant and negatively related to the production of all three vegetable production system. Therefore, an increase in labor cost by one Ghana Cedi led to a decrease in profit by Gh\$4.074 $(p<0.01)$, Gh\$44.713 $(p<0.01)$, Gh $\$ 3.657(p<0.1)$, and Gh\$0.277 $(p<0.01)$ for the production of all three vegetables, the lettuce and cabbage, lettuce and spring onion, and sole production of lettuce, respectively (Table 7). This was due to the high labor requirement of vegetable production.

Price of fertilizer is statistically significant and negatively related to combinations of lettuce and cabbage $(p<0.01)$ as well as lettuce and spring onion $(p<0.1)$. With an increase in fertilizer price by one Ghana Cedi, profitability of lettuce and cabbage production system will decrease by Gh\$45.624 and that of lettuce and spring onion production system will decrease by 18.28 (Table 7 ).

The size of land under vegetable production is negatively related to profits realized in having all three vegetables on the farm $(p<0.01)$ as well as lettuce and spring onion production system $(p<0.05)$. Increasing the size of land by 1 acre will decrease profit by Ghc 32.45 in all three vegetables production system and by Gh\$65.45 under lettuce and spring onion production system (Table 7). This is because, with large farms, farmers are unable to meet the input requirements of such farms because of inadequate access to credit (Wongnaa, 2016), leading to low yields and consequently a low profit. This however disagrees with Masuku and Xaba (2013) that there is a positive relationship between land under vegetable production and profitability of vegetable production.

\section{Constraints analysis for the various vegetable production systems}

Table 8 presents the results of Garrett's ranking method for ranking the constraints to urban exotic vegetable production. Generally, farmers ranked high input cost, land tenure insecurity, and high cost of irrigation as major challenges they faced in urban exotic 
Table 8 Rank of constraints encountered by urban vegetable farmers

\begin{tabular}{|c|c|c|c|c|c|c|c|c|c|c|c|c|}
\hline \multirow[t]{2}{*}{ Constraints } & \multicolumn{3}{|c|}{$\begin{array}{l}\text { All the three } \\
\text { vegetables }\end{array}$} & \multicolumn{3}{|c|}{$\begin{array}{l}\text { Lettuce and } \\
\text { cabbage }\end{array}$} & \multicolumn{3}{|c|}{$\begin{array}{l}\text { Lettuce and spring } \\
\text { onion }\end{array}$} & \multicolumn{3}{|c|}{ Lettuce only } \\
\hline & Total & $\begin{array}{l}\text { Mean } \\
\text { score }\end{array}$ & Ranks & Total & $\begin{array}{l}\text { Mean } \\
\text { score }\end{array}$ & $\mathrm{R}$ & Total & $\begin{array}{l}\text { Mean } \\
\text { score }\end{array}$ & Ranks & Total & $\begin{array}{l}\text { Mean } \\
\text { score }\end{array}$ & Ranks \\
\hline $\begin{array}{l}\text { High cost of } \\
\text { input }\end{array}$ & 1165 & 64.72 & $3 r d$ & 693 & 63 & 5 th & 1980 & 66 & $1 s t$ & 1431 & 75.32 & 1st \\
\hline $\begin{array}{l}\text { High postharvest } \\
\text { losses }\end{array}$ & 1168 & 64.89 & 2nd & 599 & 54.46 & 7th & 1869 & 62.3 & 4 th & 1366 & 71.89 & 4 th \\
\hline $\begin{array}{l}\text { High irrigation } \\
\text { cost }\end{array}$ & 1145 & 63.61 & 5 th & 786 & 71.46 & 2nd & 1886 & 62.87 & $3 r d$ & 1330 & 70 & 6th \\
\hline Price fluctuation & 1147 & 63.72 & 4 th & 830 & 75.46 & $1 s t$ & 1963 & 65.43 & 2nd & 1379 & 72.58 & 2nd \\
\hline $\begin{array}{l}\text { High competition } \\
\text { for land }\end{array}$ & 1058 & 58.78 & 6 th & 730 & 66.36 & 4th & 1805 & 60.17 & 5th & 1370 & 72.12 & $3 r d$ \\
\hline $\begin{array}{l}\text { Lack of access to } \\
\text { credit }\end{array}$ & 1017 & 56.5 & 7 th & 686 & 62.36 & 6th & 1646 & 54.87 & 7th & 1313 & 69.12 & 7 th \\
\hline $\begin{array}{l}\text { Land tenure } \\
\text { insecurity }\end{array}$ & 1488 & 82.67 & $1 \mathrm{st}$ & 778 & 70.73 & $3 r d$ & 1706 & 56.87 & 6th & 1362 & 71.68 & 5 th \\
\hline Sample size & 18 & & & 11 & & & 30 & & & 19 & & \\
\hline
\end{tabular}

Source: Field Survey, 2017

vegetable production (Table 8). This finding is in line with similar constraints reported in previous similar studies (Obuobie et al., 2006; Drechsel \& Keraita, 2014; Babalola et al., 2016; Kuwornu et al., 2018).

\section{Conclusions}

The focus of the study was on the profitability and constraints of urban exotic vegetable production. Generally, exotic vegetable producers in the Kumasi metropolis plant is either a single or a combination of two or more of lettuce, spring onion, and cabbage with the most common combination being lettuce and spring onion. Also, irrespective of production combination, urban exotic vegetable production in which farm produce is sold at the farm gate was found to be profitable, with monocropped lettuce being the most profitable. Because of the labor-intensive nature of vegetable production, the profitability of older farmers is lower than young ones. Farmers with large family sizes have higher vegetable farm profitability because large family sizes serve as sources of labor that supplement hired labor with which they can meet the labor demands of required cultural practices. Appreciable experience in vegetable production will increase farm performance. This is because experienced farmers have, over the years, tried and tested several vegetable production approaches and are now certain with more productive and profitable approaches. Credit will also help improve vegetable farm performance because it offers farmers the opportunity to be able to purchase all required inputs. With productivity being a necessary condition for profitability, increased productivity resulting from the use of required inputs is related to increased profitability. High prices of inputs (specifically, labor and fertilizer) were found to adversely affect farm profits. An increase in the price of labor, for instance, was found to decrease farm profits, and this is due to the high labor requirement of vegetable production, and with the wage rate being fixed across the labor activities, any increase in price of labor will increase the total cost of production and consequently decrease profits. Large farm sizes were also found to be associated with decrease exotic vegetable farm profits. This is because, with 
large farms, farmers are unable to meet the input requirements of such farms because of inadequate access to credit, leading to low yields and consequently a low profit. Finally, farmers ranked high input cost, land tenure insecurity, and high cost of irrigation as major challenges they faced in urban exotic vegetable production.

By way of helping to reduce the unemployment situation in urban centers and to help achieve the Sustainable Development Goals (SDGs) on no poverty and zero hunger, the study recommends vegetable farming to especially the youth to consider as a source of employment. Government and financial institutions are encouraged to provide especially older farmers with credit with which they can employ hired labor to be able to carry out all labor-intensive activities required for them to be efficient in their production activities. Stakeholders in the vegetable industry, especially the Ministry of Food and Agriculture may also organize production seminars or trainings for especially inexperienced producers which will afford them the opportunity to understand the technicalities whose practices will improve their performance in the vegetable production business. There is also the need for subsidies on production inputs to make their prices affordable to farmers in order for them to be able to purchase required inputs. Finally, for farmers to reap the full benefits of urban exotic vegetable production, they should analyze their production capital to be very sure that they will have enough to be able to employ all required inputs for the farm sizes they choose.

\section{Endnotes}

$$
{ }^{1} 1 \mathrm{US} \$=\mathrm{Gh} \$ 4.33
$$

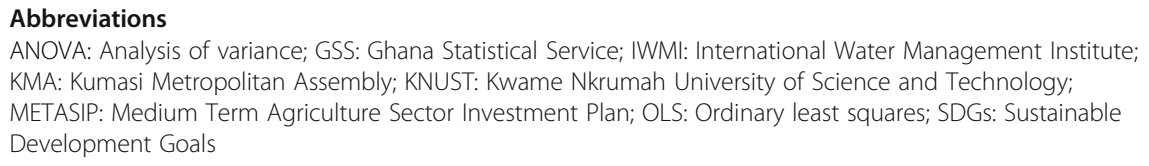

CAW conceived the idea and worked on all sections. MAA worked on the introduction as well as results and discussion. AE worked on literature relevant to the study and participated in the data collection. KSD helped in data collection and worked on the methods of analysis as well as discussion of the results. DAO participated in data collection, data entry, and data analysis. All authors read and approved the final manuscript.

\section{Publisher's Note}

Springer Nature remains neutral with regard to jurisdictional claims in published maps and institutional affiliations.

Author details

${ }^{1}$ Department of Agricultural Economics, Agribusiness and Extension, Kwame Nkrumah University of Science and Technology, Kumasi, Ghana. ${ }^{2}$ Department of Agribusiness Management and Finance, University for Development Studies, Tamale, Ghana. 
Received: 12 December 2018 Accepted: 26 March 2019

Published online: 04 April 2019

\section{References}

Abban, C. B. (2003). A comparative study on the economics of formal and informal irrigated urban vegetable production in the Greater Accra Region. Unpublished M. Phil. thesis, Dept of Agr. Economics and Agribusiness, University of Ghana, Legon. $114 p p$.

Abdulai, A.D.A.M.S. (2006). Resource use efficiency in vegetable production: The case of smallholder farmers in Kumasi metropolis (Doctoral dissertation, Kwame Nkrumah University of Science and Technology).

Abdulai, J., Nimoh, F., Darko-Koomson, S., \& Kassoh, K. F. S. (2017). Performance of vegetable production and marketing in peri-urban Kumasi, Ghana. Journal of Agricultural Science, 9(3), 202.

Adegey, A.J. and Dittoh, J.S. (1982). Essentials of agricultural economics impact publishers. Nig. Ltd Ibadan, Nigeria, pp.147-148,

Amerasinghe, P.; Cofie, O.O.; Labri, T.O.; Drechsel, P. (2013). Facilitating outcomes: multi-stakeholder processes for influencing policy change on urban agriculture in selected West African and South Asian cities. Colombo, Sri Lanka: International Water Management Institute (IWMI). 34p. (IWMI Research Report 153).

Angula, M., Thomas, B., \& ljambo, B. (2014). The economics analysis of small scale vegetable production in North Central Namibia. Universal Journal of Agricultural Research, 2(5), 141-146.

Armar-Klemesu, M., \& Maxwell, D. (2000). Accra: Urban agriculture as an asset strategy, supplementing income and diets. In Growing cities, growing food. Urban agriculture on the policy agenda (pp. 183-208).

Babalola, S. O., Adeoye, I. B., \& Adegbite, O. O. (2016). Patterns and challenges in exotic vegetables marketing. International Journal of Vegetable Science, 22(4), 376-382.

Badmus, M. A., \& Yekinni, O. T. (2011). Economic analysis of exotic vegetable production among urban Fadama women farmers in Akinyele Local Government Area Oyo State, Nigeria. International Journal of Agricultural Economics and Rural Development, 4(1), 2011.

Cofie, O., Dreschel, P., Obuobie, E., Danso, G. and Keraita, B. (2003a). Environmental sanitation and urban agriculture in Ghana. 29th WEDC International Conference "Towards the Millennium Development Goals", Abuja, Nigeria.

Cofie, O.O., Van Veenhuizen, R. and Drechsel, P. (2003b). Contribution of urban and peri-urban agriculture to food security in sub-Saharan Africa. Africa Day of the 3rd WWF in Kyoto, pp.17-13.

Cornish, G. A., \& Lawrence, P. (2001). Informal irrigation in peri-urban areas: A summary of findings and recommendations. In DFID's water KAR project R7132, report OD 144. Wallingford: HR Wallingford 54p.

Danso, G., Drechsel, P., Wiafe-Antwi, T., \& Gyiele, L. (2002). Income of farming systems around Kumasi. Urban Agriculture Magazine, 7, 5-6.

Demiryurek, K., \& Ceyhan, V. (2008). Economics of organic and conventional hazelnut production in the Terme district of Samsun, Turkey. Renewable Agriculture and Food Systems, 23(3), 217-227.

Diao, M. B. (2004). Situation et contraintes des systèmes urbains et périurbains de production horticole et animale dans la région de Dakar. Cahiers Agricultures, 13(1), 39-49.

Drechsel, P., \& Dongus, S. (2010). Dynamics and sustainability of urban agriculture: Examples from sub-Saharan Africa. Sustainability Science, 5(1), 69 .

Drechsel, P., Graefe, S., Sonou, M., \& Cofie, O. O. (2006). Informal irrigation in urban West Africa: An overview (Vol. 102) IWMI. Drechsel, P. and Keraita, B. (2014). Irrigated urban vegetable production in Ghana: Characteristics, benefits and risk mitigation. IWMI.

Garett, H. E., \& Woodworth, R. S. (1969). Statistics in psychology and education (p. 329). Bombay: Vakils, Feffer and Simons Pvt. Ltd. Gerstl, S. (2001). The economic costs and impact of home gardening in Ouagadougou, Burkina Faso (Doctoral dissertation, University_of_Basel).

Gockowski, J., Mbazo'o, J., Mbah, G., \& Moulende, T. F. (2003). African traditional leafy vegetables and the urban and periurban poor. Food Policy, 28(3), 221-235.

GSS. ( 2014). Ghana statistical service. Gross Domestic Product, 2014.

Gyiele, L. (2002). Integrated economic and environmental impact assessment of urban and peri-urban agriculture in and around Kumasi. Vol. 1: Financial analysis. Final report submitted to FAO (Project PR 17951). Kumasi: IWMI-IBSRAM-KNUST.

Hoornweg, D. and Munro-Faure, P. (2008). Urban agriculture for sustainable poverty alleviation and food security. Position paper, FAO. Africa.

Judicom. (2004). Étude pour l'élaboration du plan de développement de la filière fruits et légumes au Burkina Faso. Ministère de l'agriculture, de l'hydraulique et des ressources halieutiques, Ouagadougou, Burkina Faso.

Kassali, R. (2011). Economics of sweet potato production. International Journal of Vegetable Science, 17(4), 313-321.

Kessler, A., Streiffeler, F., \& Obuobie, E. (2004). Women in urban agriculture in West Africa. Urban Agriculture Magazine, 12, 16-17.

KMA. (2016). Kumasi metropolitan assembly. The composite budget of the Kumasi metropolitan assembly for the 2016 fiscal year.

Kouamé, C., Temple, L., Levasseur, V., \& Pasquini, M. W. (2006). A review of urban and peri-urban vegetable production in West Africa. In XXVII International Horticultural Congress-IHC2006: International Symposium on Horticultural Plants in Urban and Peri-Urban 762 (pp. 245-252).

Kouvonou, F. M., Honfoga, B. G., \& Debrah, S. K. (1999). Sécurité alimentaire et gestion intégrée de la fertilité des sols: La contribution du maraîchage péri-urban à Lomé. In O. B. Smith (Ed.), Agriculture urbaine en Afrique de l'Ouest: une contribution à la sécurité alimentaire et à l'assainissement des villes. Ottawa: IDRC-CTA.

Kuwornu, J. K., Oduro, E., Amegashie, D. P., Fening, K. O., Yangyouru, M., MacCarthy, D. S., ... \& Datta, A. (2018). Cost-benefit analysis of conventional and integrated crop management for vegetable production. International Journal of Vegetable Science, 24(6), 597-611.

Lee-Smith, D. and Prain, G. (2006). Understanding the links between agriculture andhealth. IFPRI, focus 13, www.ifpri.org

Mariyono, J. (2018). Profitability and determinants of smallholder commercial vegetable production. International Journal of Vegetable Science, 24(3), 274-288.

Masuku, M. B., \& Xaba, B. (2013). Factors affecting the productivity and profitability of vegetables production in Swaziland. Journal of Agricultural Studies, 1(2), 37-52.

Mbaye, A., \& Moustier, P. (2000). Market-oriented urban agricultural production in Dakar. In N. Bakker, M. Dubbeling, S. Gündel, U. Sabel-Koschella, \& H. de Zeeuw (Eds.), Growing cities, growing food: Urban agriculture on the policy agenda (pp. 235-256). Germany: DSE-Sida-CTA-GTZ-ACPA, DSE.

Moustier, P., Moumbele, M., \& Huat, J. (2004). La gestion concertée et durable des filières maraîchères urbaines. In O. B. Smith, P. Moustier, L. J. A. Mougeot, \& A. Fall (Eds.), Développement durable de l'agriculture urbaine en Afrique francophone: enjeux, concepts et méthodes (pp. 79-113). Ottawa: CIRAD-CRDI. 
Ndungu, S. K., Macharia, I., \& Kahuthia-Gathu, R. (2012). Analysis of profitability of organic vegetable production system in Kiambu and Kajiado counties of Kenya. In African crop science conference Proceedings11 (pp. 605-611).

Obosu-Mensah, K. (1999). Food production in urban areas. A study of urban agriculture in Accra, Ghana (p. 227). Aldershot: Ashgate Publishing.

Obuobie, E., Keraita, B., Danso, G., Amoah, P., Cofie, O. O., Raschid-Sally, L., \& Drechsel, P. (2006). Irrigated urban vegetable production in Ghana: Characteristics benefits and risks. Accra: IWMI-RUAF-CPWF.

Okurut, F. N., \& Botlhole, T. (2009). Informal financial markets in Botswana: A case study of Gaborone City. Development Southern Africa, 26(2), 255-270.

Oxouzi, E., \& Papanagiotou, E. (2010). Comparative analysis of organic and conventional farmers and their farming systems. Where does the difference lie? Bulgarian Journal of Agricultural Science, 16(2), 135-142.

Temple, L., Minkoua, R., Nkendah, R. and Marquis, S. (2005). Impact de l'urbanisation sur l'intensification des systèmes de production horticoles au Cameroun. Proc. Agriculture and Urban Development in West and Central Africa Workshop, Yaounde, Cameroon, 31 October - 03 November.

Van Veenhuizen, R., \& Danso, G. (2007). Profitability and sustainability of urban and periurban agriculture (Vol. 19). International Water Management Institute (IWMI), Ghana. Rome: Food \& Agriculture Organization of the United Nations.

Wongnaa, C. A. (2016). Economic efficiency and productivity of maize farmers in Ghana (Doctoral dissertation). Kumasi: Kwame Nkrumah University of Science and Technology.

Yamane, T. (1967). Elementary sampling theory prentice Inc. Englewood Cliffs. NS, USA, 1, pp.371-390.

Zallé, D. (1999). Les stratégies politiques pour l'agriculture urbaine, rôle et responsabilité des autorités communales: Le cas du Mali. In O. B. Smith (Ed.), Agriculture urbaine en Afrique de I'Ouest: Une contribution à la sécurité alimentaire et à l'assainissement des villes. Ottawa: IDRC-CTA.

Submit your manuscript to a SpringerOpen ${ }^{\circ}$ journal and benefit from:

- Convenient online submission

- Rigorous peer review

- Open access: articles freely available online

- High visibility within the field

- Retaining the copyright to your article

Submit your next manuscript at $\boldsymbol{\nabla}$ springeropen.com 